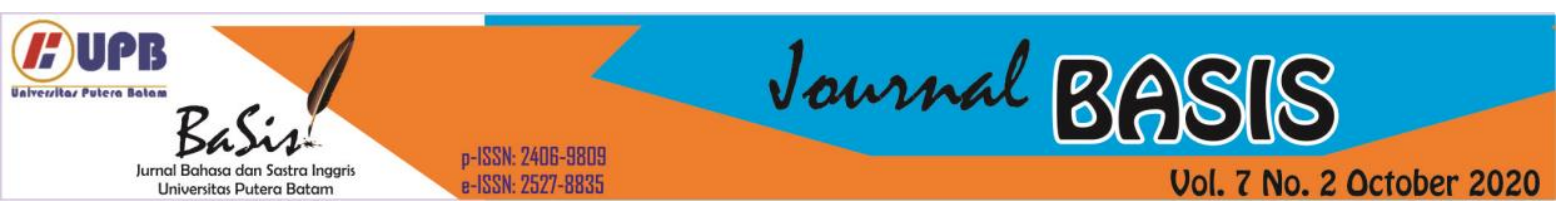

\title{
SOCIAL CLASS CONFLICT REFLECTED IN "FAR FROM THE MADDING CROWD" NOVEL BY THOMAS HARDY
}

\author{
Manuela Indriati Siahaan ${ }^{1}$ \\ Universitas Putera Batam (UPB), Batam, Indonesia \\ pb151210043@upbatam.ac.id \\ Tomi Arianto ${ }^{2}$ \\ Universitas Putera Batam (UPB), Batam, Indonesia \\ Tomi.arianto@puterabatam.ac.id
}

\begin{abstract}
This research aimed to analyze social class conflict reflected in novel of Far from the Madding Crowd by Tomas Hardy. This descriptive qualitative research focuses on the social class conflict in England which is reflected in this novel. This study uses a sociological approach and analyzes the distribution of social classes in this novel and the social class conflicts that occur in this novel. The method used in writing this thesis is a qualitative descriptive method, namely the author describes, memorizes, and analyzes existing data. Quotations from books in libraries and the internet related to this research. The theory used is the theory of sociology with experts Max Weber and Karl Max.. The theory proposed by Karl Marx is an explicit theory, based on Marx's description of the laws of historical development, capitalism and socialism. Theory of sociology is used to analyze the social class divisions that exist in this novel while Maxisme class theory analyzes the conflicts. The results are have featured three male characters who became the main characters are Mr. Boldwood, Mr. Troy and Mr. Oak coming from three different classes of lower classes, middle classes, and upper classes. The social that happen among of three male character are: First, Bribery are shown conflict between $\mathrm{Mr}$. Boldwood and Mr. Troy are representation to Upper Class and Middle Class. Second, Arrogance are shown conflict between Mr. Boldwood and Mr. Troy are representation to Middle Class and Upper Class. Third, are shown conflict between Mr. Troy and Mr. Oak are representation to Middle Class and Lower Class.
\end{abstract}

Keywords: sociological approach, social class conflict, social class

\section{INTRODUCTION}

Literature is an art form and an expression of human nature and important human experience. Literature may also formed in a non-book or unwritten works such as films, recordings, and others who can provide information. Novel is one of the ways to communicate in literature. Novels are prose fiction which is usually can find in the style of narrative. Novel tells about story, which is usually define as a series of events that are described in sequence. Through novels, author can explore human's behavior, attitude, appearance, and character that can be observed from joys, sorrows, struggles, successes, failures, and social classes condition.

In this research aimed to analyze the social class conflict reflected in "Far from the Madding Crowd" novel (1879) by Thomas Hardy, who is analyzed about love conflict. "Far from the Madding Crowd" is a romantic novel that was setting in England and it was adapted into a popular film of the same name in 2015. This novel is Thomas 
Hardy's fourth novel and first major successful literary. This novel consist of 464 pages and published in 1874 by Cornhill Magazine as a publisher. Many people are interesting with this novel, this novel got predicate as a hardcover best seller for more than a year. This novel tells about love and romance that two suitors that come from a different status or class each other to get one woman.

Therefore, it is important for the writer to conduct research as an example of analysis for humans as well as for readers as a priority after reading the novel. A writer needs an approach analyze this novel is sociological approach. According to Weber (1964), thereby to arrive at a casual explanation of its course and effect.

\section{LITERATURE REVIEW}

2.1. Theory of the research

In this research, there are two types of theory that can used; they are theories about social class and social classes conflict. Furthermore, to analyze these literary works, researchers first need to apply a theory or approaches. Researcher analyzed this thesis by used sociological approach. In this research, the theories that used is the theories of Karl Max and Max Weber, the sociological theory, because this thesis related to social class conflict. Sociological approach can used if the story reflects about social classes conflict of society in certain time.

One of Literature branches is Novel. The meaning of novels are books of long narratives in literary prose. Novel is one of the ways to communicate in literature. Novel is the most of literature work in world. Novel was begin in Victoria Period. Novel can analysis with some of Approach. The one of them is Sociological Approach. Sociological Approach have some about theories. To describe about The types of Social Class, the researcher used by theory of Max Weber.

According to Weber (1978), writes that a classroom situations is a situation in which there is a general possibility of obtaining goods, getting ranked in, and finding inner satisfaction ': in other words, class members share equal opportunities in life. If this is what class members have, what puts them in this common position? The answer of Weber is that The market of opportunity lives on according to the resources brought by the individual, and he realizes that these resources can vary in a number of ways. In addition to the differences between owners and non-owners, there are variations according to specific skills and other assets. However, the important point is that all these assets have value only in the context of the market: therefore, the class situation is identified with the market situations.

For the types of Social Classes Conflict, the researcher used theory of Karl Max. The name of his theory is Marxism. Marxism is a theory of social founded by Karl Marx and Friedrich Engels. The theory of Marxism focuses on the representation of social conflicts between capitalists and the working class. Based on the theory of Marxism, humans have different functions in economic activities; these differences lead to social class in 17 societies. "The division of labor leads to the development of class society; in which the population of society is divided into separate classes whose needs and wants may be fundamentally conflicting" Booker, (1996). The resistances of working class to the oppression of the capitalists during the uprising in which the working class wanted and got a better life.

Marxist Literary Theory is the cultural theories that embody the socioeconomic associations, and the political 
ideas which their followers believe will enable them to interpret and change their world. This theory suggests that class conflict and workers' struggles are so entrenched in society that they are reflected in literature, returning to the notion that their superstructure reflects the basis. Superstructure (law, politics, art, morality, religion) is a reflection / result / expansion of the basis (means of production, agriculture, industry, crafts). Is considered the path that humanity must take in the end.

\subsection{Previous Study}

There are several studies that are sufficient to contribute to this research but still have differences from several sides. The first research was written by Farida (2020) about analysis of The Lord of the Rings oleh JRR Tolkien. Farida analyzed the state of the simulacrum by using a sociological approach to indicate what was real and not real in the novel. In contrast to what did the researchers focus on social class conflict.

Futhermore, the article written by Waworuntu \& Arianto (2019) discussed about the analysis of hybridity and mimicry toward the characters in My Son the Fanatic. Various kinds of conflicts between a child and a father who have different ideologies are contested in this story. Parvez and Ali became representatives of two easterners who lost their identities. They contest each other to show the truth but on the contrary fall into postcolonialist construction. Arianto \& Simanjuntak (2019) furthermore it also analyzed the conflict behind the story of the spirit of Mak Ungkai Story. This legendary Malay mythical story becomes a paradoxical representation of the manifestation of a woman who is shown to be turned around. On the one hand, worshiped on the other hand as the keeper of the balance of nature.
Another references that cpuld be discussed in this part is written by Arianto (2019) about the conflict between two legendary Japanese samurai. Conflicts are presented by showing formulas in popular literature so that readers realize that popular literature cannot be separated from elements of capitalism. Linda \& Arianto (2018) Likewise, it perpetuates a children's story conflict with the presence of a formula that makes a unity of myth a justification because of the producer's greatness in composing the story.

Arianto (2017) in another article also presents a sociological analysis of literature related to the view of death. Arianto raised the theme of modern people's views on death in the novel My Sister Keeper. Sipahutar \& Arianto (2019), It is different again to view the conflict that occurs in Walt Whitman's poetry by using the Riffatere approach. Although various references to social conflict are shown above, the researchers still carry a different theme, namely related to social class conflict.

\section{RESEARCH METHOD}

This research used descriptive qualitative method. The researcher describes the whole process of the step to solve the problem in the problem formulation. The whole research process starts with the phenomena the researcher finds when reading a Thomas Hardy's novel. The researcher takes social class conflict and social literature. The story of the novel "Far from the Madding Crowd" by Thomas Hardy are dominated by social class. The social class is study of the sociological approach, The research is a kind of qualitative method, which as a purpose to reveals the hide value in the story and used the researchers as a instrument (Sugiyono, 2015 p.8) The research method includes research procedures 
from preparation to final research. Methods that include data, data analysis methods, and methods of presenting research results.

The object of research is the problem that the researcher analyzes. According to (Prof. Dr. Sugiyono, 2009 p.38), object of the research is an attribute or character of people, objects or activities with certain varieties and set by the researcher to be analyzed and concluded. It means that object of the research, the researcher needs to pick the literary work written by Thomas Hardy.

The researcher used documents of study to collecting the data. Document study means the data are collected from writing works, pictures, and soon (Sugiyono, 2009:240). This activity collects scientific data or information such as theories, methods or approaches from books, journals and other documents. In the other words, this method focuses on the interpretation of the written materials based on the context (Sugiarto, 2015:12). This means that document study is a text-based databased method for context.

The data analysis method includes two main steps; analyze the intrinsic and extrinsic elements of the story from the novel. The first step is to research intrinsic or fictional elements which means a set of aspects in fiction that are built from within the story itself (Aminuddin, 2013: 66). So in this chapter the researcher is about analysis that is not in the analysis which consists of plot, character, setting, point of view, and theme. For extrinsic research, researchers get data from sources such as books or e-books.

\section{RESEARCH ANALYSIS AND FINDING}

\subsection{Research Analysis}

Fictional elements include characters, plot, setting, viewpoints and themes. Analysis of fictional elements is present as a preliminary and revised analysis using words or paragraphs and is supported by quotations from the novel to ensure the analysis.

\subsubsection{Character}

In the novel, which is divided into two categories, there is a mayor character as someone who has a dominant role in the story, they play an important role in creating and solving big problems and a minor character as someone who only helps the main character and he doesn't always come. in the story. In this study the researcher found several characters which were discussed as follows:

a. Batsheba Everdane

The protagonist in this novel and she is also the main character on this novel which also drives the plot through its interactions with various suitors.

b. Gabriel Oak

This character include to protagonist character and he is also major character because on this novel's hero.

\section{c. Sargent Francis (Frank) Troy}

The novel's antagonist because he has bad desires to marry with until he try to control wealth of Batsheba Everdane and his also major character because he is the one of suitors that who loved and marry with Batsheba.

d. William Boldwood

This character include to protagonist character and he is also major character. Batsheba's second suitors and as a owner of the nearby farm.

e. Fanny Robin

This character include protagonists and minor characters. An orphaned servant girl on the farm who runs away on the night Gabriel arrives, tries to marry Sergeant Troy, and ends up dying give birth to her child in the poor house in Caster bridge and was an obstacle to Bath, shown the fate of women who were not cared for in this society well. 
f. Liddy Smallbury

The minor character on this novel and as maid of Bath.

g. Jan Coggan

The minor character on this novel. Farm laborer and friend to Gabriel Oak.

h. Joseph Poorgrass

The main character on this novel. A shy and shy farm worker who blushed. Handily, Poorgrass brought Fanny's coffee from Caster bridge back to the farm for the funeral.

i. Cainy Ball

The main character on this novel. A young man who works as Gabriel Oak's assistant shepherd on the Everdane.

j. Pennyways

A bailliff on the Bathsheba farm who was caught in the grain and was laid off. She disappeared for most of the novels until she accepted Troy at the Greenhill Fair and helped Troy surprise Bathsheba at the Boldwood Christmas party.

\subsubsection{Plot}

The plot is a reflection or even the journey of the characters acting, thinking, feeling and behaving in dealing with life's problems. A literary term, plot is any event in a story that is specifically devoted to the achievement of some artistic or emotional effect or a certain general theme.

1. Exposition is the beginning plot that concerned to introduce the characters and setting. This exposition start when Batsheba Everdane is a young beautiful woman that has three suitors who has a purpose to marry her. First suitors is Gabriel Oak as a farmer.

2. 2. Rising Action is a series of complications that lead to the moment of great attention. This rising action started when a rich and old farmer named Boldwood also wanted to marry her. But before he can seduce her, he runs off and a man named Sargent marries an arrogant young man named Frank Troy. 3 . The climax is the culmination of the story, when the climax of the conflict creates a climax of conflict and begins when Troy disappears, Boldwood tries to enter his territory and marry Bathsheba. Just when he might agree, even though Troy reappears because he is tired of living without Bathsheba's money. This time, Boldwood was unable to request the news, so he looted a rifle and shot Troy in the chest, killing him. So Troy is dead and it looks like Boldwood will be executed.

4. Falling action is a series of events that follow the climax and end the story. It started when Gabriel Oak told Bathsheba that he was planning to move to America, he asked her to stay because he has always been good friends. She agrees to stay if they get married, and their complaints do.

\subsubsection{Setting}

According to Kenney, settings are "the elements of fiction which reveals where and when the events happens". In the other hands, the term "setting" discuss about the point of time and place. "Far from The Madding Crowd" is the fictional area of Wessex, England.

\subsubsection{Point of View}

Point of view refers to the narrator or storyteller. Thomas Hardy, like many Victorian novelists, was the third omniscient fan. The point of view will give you insight into the different characters and because the writer is an omniscient figure.

\subsubsection{Theme}

The writer finds out that the theme of Thomas Hardy's novel is about Marriage It seems like marriage is always on the mind of one of the main characters. First, Gabriel wanted to 
marry Bathsheba and then Boldwood married and also Troy.

\subsection{Research Finding}

In the novel, the researcher found that there were different class differences in the society. British society often falls into three main groups: Upper Class, Middle Class and Lower Class. The first step is to classify each character into each social class according to Max Weber's theories of Lower Class, Middle Class, and Upper Class. The second step is to compare conflict conflicts that occur in this novel by using the theory of Karl Max.

\subsubsection{Upper Class}

In social science, "upper class" is a group of people in a group of people who are at the top of the social hierarchy. Upper class members may have large powers over resource allocation and government policies in their territories. Historically in some cultures members of the upper classes were not allowed to work for a living, because they were supported by investments that were earned or passed on, even though members of the upper classes might have real money.

The novel's first social class is William Boldwood. The upper class was dominated by political and financial problems which was the love of British society in general at the time. As researchers found from the quote below:

"Boldwood was tenant of what was called Little Weatherburry Farm, and his person was the nearest approach to aristocracy that this remoter quarter of the parish could boast of genteel strangers, whose god was their town." (p. 93)

The quotation above, already mentioned in the introduction establishes Sir William Boldwood has farm named
Little Weatherburry, so he include to Upper Class.

\subsubsection{Middle Class}

The middle class is a class of people who are in the middle of the hierarchy of society. In Weberian socioeconomic terms, the middle class is a large group of people in contemporary society who are between the lower and upper classes.

Most sociological middle class definitions are followed Max Weber. According to Max Weber (1978:p.302), The middle class is defined as consisting of owners of professionalism who share a domestic culture and sub-urbanity and a lot of security relative to social criticism.

"He was a fairly well-educated man for one of middle class exceptionally well educated for a common soldier. He spoke fluently and unceasingly." (p.132)

The quotation above, already mentioned in the introduction Sergeant Frank Troy a man from a middle class and he also a soldier. So he include to Middle Class.

\subsubsection{Lower Class}

The lower class is characterized by poverty, homelessness and unemployment. The people in this class, only a few of them who have graduated from high school, suffer from a lack of medical care, adequate housing and food, proper clothing, security and vocational training. The media often stigmatize the lower class as "lower class", inaccurately characterizing the poor as welfare mothers abusing the system with more babies, prosperous fathers who can work but can't, drug abusers, criminals. One of the supporting supporters of the above we can see from the quote below: 
"Gabriel's farm had been stocked by a dealer - on the strength of Oak's promising look and character - who was receiving a percentage from the farmer till such time as the advance should be cleared off." (Chapter 5 p.31)

The quotation above can concluded that, Mr. Oak was homelessness because it was a storm that destroyed his farm. So, he got lost everything that he has.

\subsubsection{Social Class Conflict as reflected in the Novel \\ 4.2.1.1 Bribery}

The researcher find some conflict on this novel that representation of the social class. First Conflict is Bribery. We can see from the quotation below:

"I'll pay you well now, I'll settle a sum of money upon her, and I'll see that you don't suffer from poverty in the future. I'll put it clearly. Batsheba is only playing with you:you are too poor for her as I said; so give up wasting your time about a great match you'll never make for a moderate and rightful match yo may make tomorrow,take your carpet-bag,turn about, leave Wetherbury ow, this night and you shall take fifty pounds with you." ( $p$ 180)

The quotation above is taken when the story tell about the meeting of William Boldwood and Sargent Troy. In the quotation, the researcher observed that Mr. Boldwood trying to bribe $\mathrm{Mr}$. Troy to ask that he leave Batsheba. According to Weber Lower class prestige, social honor, or popularity in society. Weber noted that politics is not only rooted in the value of capital, but also in the individual status of a person. Poets or saints, for example, can have a profound influence on societies of little economic value. So, the researcher concluded that Mr. Boldwood from this attitude shows Mr. Boldwood uses every way to get what he wants. So,the researcher concluded that is one form of conflict between Upper Class and Middle Class as reflected in this story.

\subsubsection{Arrogance}

The second conflict is named Arrogance. We can see from the quotation below:

"I like Fanny best,' said Troy; and if, as you say, Miss Everdane is out of my reach, why I have all to gain by accepting your money, and marrying Fan. But she's only servant.'

"Never mind- do you agree to my arrangement? 'I do'.

'Ah!' said Boldwood, in a more elastic voice. ' $O$ Troy, if you like her best, why then did you step in here injure my happiness?'

'I love Fanny best now,' said Troy.

'But Bathsh. Miss Everdane inflamed me, and displaced Fanny for a time. It is over now. (p.180)

The quotation above is taken when the story tell about the meeting of William Boldwood and Sargent Troy where is Mr. Troy accepted the bribe granted from Mr.Boldwood to him. The reason researchers categorize Mr. Troy cocky is he does not want to marry Fanny because the woman is just a waiter from this side look how arrogant his Mr. Troy when he likes Fanny as well. 'I love Fanny best now,' said Troy. 'But Bathsh. . . Miss Everdane inflamed me, and displaced Fanny for a time. It is over now." From this word the researchers also concluded that Troy is arrogant because he has a handsome face so he can play with love and also women. So the researcher analyzed this is one form of conflict between Middle 
Class (Troy) and Upper Class (Boldwood) as reflected in this story.

\subsubsection{Bribery Rejection}

The quotation below is taken when the story tell about the meeting of Sergeant Troy, Coggan, and Gabriel Oak where is Mr. Troy want see Mr. Boldwood but did not see him so he only met with Coggan and Mr. Oak. We can see from the quotation below:

"Troy threw the coin dexterously across the front plot and over the fence towards Gabriel, who shunned it in its fall, his face turning to an angry red. Coggan twirled his eye, edged forward, and caught the money in its ricochet upon the road."

"Very well - you keep it Coggan,'said Gabriel with disdain and almost fiercely.'As for me, I'll do without gifts from him!"' (p.187)

The quotation above that shows the tension between Oak and Troy. It could be seen when Troy tossed a bribe coin from Mr. Boldwood to him to face Oak, Oak is very angry. So this is an example of conflict that occurs between Lower Class and Middle Class.

\subsubsection{Conflict among three suitors of} Batsheba Everdane as Reflection of Social Class

Here the researcher discusses about characters of three suitors that represented the Social Class.

\subsubsection{Gabriel Oak as Representation of Lower Class}

\subsection{Loyal}

Loyal represents the Lower Class. The researcher concluded that what distinguishes the other characters in this novel is his loyalty to Bathsheba Everdene. Even when Bathsheba refused a marriage request, she claimed:
"I shall do one thing in this lifeone thing certain - that is, love you, and long for you, and keep wanting you till I die" (Chapter 4 line .65).

The above quotation can stop stating that the tree's suffering continued to plague Bathsheba until she relented or took pity. He had too much prestige to do such a thing, and besides, he didn't want Bathsheba to marry him if he didn't love her. To show it to Bathsheba, Oak brings her 'in his arms a new-born lamb' (Chapter 2 line 13) in the hope that she would raise it. It doesn't takes a big leap to judge this lamb as a symbolic child, signifying Oak's desire to one day marry Bathsheba. But the funny things is that for most of this book, Oak has literally kept his love for Bathsheba. Only at the end of the story when Bathsheba asked him not to leave her did he keep her previous promise and said that he still loved her.

\subsubsection{William Boldwood as} Representation of Upper Class

\subsection{Dignity}

The first things we learned about Farmer Boldwood is that he is a truly dignified man. As the author told based on the quote below:

"He was erect in attitude, and quiet in demeanour. One characteristic pre-eminently marked him: dignity". (Chapter 12 line 14).

The above quote can state that the man was loaded. He was around 40 years old, but many women in Weatherbury pursued him quite aggressively, hoping he would propose to them but none of them made it until Bath sent him a Valentine card, "Marry $\mathrm{Me}^{\prime}$ on it. The problem was Bathsheba never wanted him to see who sent him, she did it just for fun. And now we find out about the deeper layers of the 
Boldwood character. In the words of the narrator, "If an emotions possessed him at all, it ruled him: a feeling not mastering him was entirely latent" (Chapter 18 line 6). The man became very obsessed with his love for Bathsheba. He is so obsessed with her, he doesn't even care if she doesn't loved him too. He only wanted her to be his wife. Now as you can imagine, it's hard to go from being a guy who has always controlled his image and behavior throughout his life, to a school girl crush. But the concern that people noticed about him when he was rejected by Bathsheba: "There was a changes in Boldwood's exterior from its former impassableness: and his face showed that he was now living outside his defences for the first time, and with a fearful sense of exposure" (Chapter 18 line 12). Poor man hates to be vulnerable in situations like this, and this feeling of vulnerability ultimately causes him to attack and kill Sergeant Troy, effectively ending his life as well.

\subsubsection{Sergeant Troy as Representation by Middle Class}

\subsection{Cocky}

Sergeant Troy is the typical of cocky or conceited young man who think that the best ways to make women like him is lie to them and it works for him. There are many women love him. Take, for example, her engagement to Fanny Robin. When Fanny appeared and asked her to marry her Creator, Troy could only stumble over what he said based on the quote below:

"The fact is I forgot to ask [permission to leave]. Your coming like this is so sudden and unexpected" (Chapter 11 line 61).

The quotation above can be concluded that he continues to serve his marriage as long as possible like a good man. Despite his reputation as a seducer, people still have divided opinions about him. Tendency, he comes from a respectable family and has a high level of education. Servant Liddy best shows this divided opinion if he says to Bath based on the quote below:

"O miss - I blush to name it - [he is] a gay man-a walking ruin to honest girls, so some people say. But I know him to be very quick and trim, who might have made his thousands as a squire" (Chapter 24 line 65).

The quotation above can be concluded that people in Tomas Hardy's time (like today) aren't too hard on a guy for being a player, so long as they're charming and fun to be around and that is exactly what Sergeant Troy is. You might not like Sergeant Troy, but the guy isn't entirely evil. He just has his own styles of living life that concern to hurt people or as the narrator says:

"He was a man to whom memories were an encumbrance and anticipations a superfluity. Simply feeling, considering and caring for what was before his eyes he was vulnerable only in the present" (Chapter 25 line 2).

The above quote could state that Troy is a man who actually lives in the here and now. But even that all changed when Fanny Robbin died, along with the child she and Troy had together. The horror of this event finally reaches Troy's heart, and the man realizes that he will never love anyone who loves Fanny Robbin.

4.2.1.4 Batsheba Everdane

\subsection{Vain}

In this section, courtesy of Bathsheba Everdene, the researcher 
concludes that When Gabriel Oak was watching her from across the field, the first thing he saw was based on his quote below:

"a small swing looking-glass was disclosed [in her hand], in which she proceeded to survey herself attentively. She parted her lips, and smil ed" (Chapter 1 line 13).

From the above quote it can be stated that Bathsheba liked to look at herself in the mirror when she did not think anyone was watching. It's really not paying attention to yourself in the window reflection before realizing that someone on the other side of the window is looking at you. Awkward.

What really struck Oak about Bathsheba's vanity was her sharp edge. Looking in the mirror to straighten out your appearance is one thing, but he realizes it immediately "there was no necessity whatever for her looking in the glass. She did not adjust her hat, or pat her hair, or press a dimple into shape " (Chapter 1 line 15). This vanity is something that continues to appear later in this book, ultimately condemning God for such a wonderful fact.

\subsubsection{Independent}

Despite her vain, Bathsheba remains a highly respected person in the novel, mainly because of her independent ways as a woman living in 19th century England. We can see these signs of freedom from the start when Bathsheba decided to ride her horse like a man with one leg on either side of the saddle. For her aunt (and most Victorians), this was a sex scandal. But that Bathsheba confidently all agreed based on the quote below:

"I can ride on the other [saddle]: trust me" (Chapter 2 line 31).
From the above quote it can be argued that Bathsheba really showed what she was made of when she decided to fire her farm manager and run to the place herself. For the men working under her, this was an unthinkable thing to do. He went on to do an excellent job running the farm, which panicked greatly.

\section{CONCLUSION}

Based on the researcher analysis, the researcher conclude that in Novel of From analyzing novel, the writer learns more about various characters throughout the story. From the characters, the writer learns about their behaviors and personalities.

In "Far From the Madding Crowd", the researcher finds out that the main character is independent, loving freedom and trust about true love. Batsheba Everdane as a main character on this novel, she contested by three suitors that a representation of different social class. Classify to Lower, Middle, and Upper Class. The second is the researcher finds out that character of three suitors can match from social class of them. Social class conflict reflected in the novel of Thomas Hardy "Far from the Madding Crowd" are there found conflict that saw it event that conflict between the difference class. Because of that, the lower class feel oppression from the middle class and upper class. Based on the above opinion, the results of this study can provide input to the next several parties.

\section{REFERENCES}

Aminuddin. 2013. Pengantar Apresiasi Karya Sastra. Bandung: Sinar Baru Algensindo

Anisa, Dwi Listi. Social class and Social Reality of British Society as reflected in Pride and Prejudice by 
Jane Austen; A Sociological Approach. 2012. Putera Batam University.

Arianto, T. (2017). Death as Instrument of Power in the novel My Sister Keeper by Jodi Picoult. Basis, 4(April 2017), 46-58. http://ejournal.upbatam.ac.id/index. $\mathrm{php} / \mathrm{basis} /$ article/view/78

Arianto, T. (2019). The analysis of formula in the legend of japanese samurai rurouni kenshin and miyamoto mushasi: popular literary approach. Jurnal BASIS, 6(1), 5564. https://doi.org/https://doi.org/10.33 884/basisupb.v6i1.1047

Arianto, T., \& Simanjuntak, D. S. (2019). Paradoxical Representation of Female Narration in the Spirit of Mak Ungkai StoryNo Title. Journal BASIS, $\quad 6(2), \quad 173-184$. https://doi.org/https://doi.org/10.33 884/basisupb.v6i2.1413

Booker, M. K. dan Thomas, A. M. (2009). The science fiction handbook. Chichester: John Wiley and Sons

Dubois, W. E. B. (1996). Ladder for Booker T. Washington, 1996. 8889.

Farida, Hana. (2020). Being Human Among Otherkins:Identifying The Simulacrum In Jrr Tolkien's The Lord Of The Rings. Jurnal Basis, v. 7, n. 1, p. 81-90, apr. 2020. ISSN 2527-8835. Available at: http://ejournal.upbatam.ac.id/index. php/basis/article/view/1817

Hariyanti, Mei. 2013. Social Strafication Reflected at Jane Austen's Pride and Prejudice Novel (1813); A Sociological Approach. Putera Batam University

Kuipers, B.S., Higgs, M.J., Kickert, W.J.M., Tummers, L.G., Grandia, J., dan Van der Voet, J. (2014). The Management of Change in Public Organizations : A Literature Review. International Journal of Public Administration.

Lexy.J. Moleong, Metodologi Penelitian Kualitatif Bandung : Remaja Roskakarya, 2000

Linda, L., \& Arianto, T. (2018). Child Literature Genre Formulation in Walt Disney Animation Movie. Jurnal Basis, 5(2), 11. https://doi.org/https://doi.org/10.33 884/basisupb.v5i2.776

Lofland dan Lofland dikutip oleh Dr.Lexy J Moleong, Metode Penelitian Kualitatif, Bandung : Rosdakarya, 2006

Londong, Pamela Clara. Literature that Reflected in Pride and Prejudice. Manado. Sam Ratulangi University. 2008

Max weber. (1978). Max Weber. (1922) 1978. 1922, 1978.

Sipahutar, R., \& Arianto, T. (2019). An Analysis of Semiotic Riffaterre in Walt Whitman Selected Poem. Journal BASIS, 6(2), 237-248. https://doi.org/https://doi.org/10.33 884/basisupb.v6i2.1428

Sudaryanto. 1993. Metode dan Aneka Teknik Analisis Bahasa ( Pengantar Penelitian Wahana Kebudayaan Secara Linguistis ). Yogyakarta: 
Duta Wacana University Press.

Stanton, Robert. 1965. An Introduction to Fiction. New York: Holt, Rinehart and Winston.

Sugiyono. 2011. Metode Penelitian Kuantitatif, Kualitatif dan $R \& D$. Bandung: Afabeta

Suwondo, Tirto, dkk. 2006. Antologi Biografi Pengarang Sastra Modern. Yogyakarta: Adi Wacana.

Swingwood. Allan (n.d.). The Sociology of Literature. 1st November by Harper Collins. Retrieved from
Max weber. (1978). Max Weber . (1922) 1978., (1922), 1978.

Waworuntu, M. I. G. R., \& Arianto, T. (2019). Hibridity of the Characters in My Son The Fanatic Short Story by Hanief Kureshi. BASIS UPB, 6 , 197-208. https://doi.org/https://doi.org/10.33 884/basisupb.v6i2.1432

Wellek, R., \& Warren, A. (1956). Theory of literature [by] René Wellek and Austin Warren. New York: Harcourt, Brace \& World. 